\title{
Why Do Consumers Choose Photovoltaic Panels? Identification of the Factors Influencing Consumers' Choice Behavior regarding Photovoltaic Panel Installations
}

\author{
Magdalena Grębosz-Krawczyk ${ }^{1}$ (D), Agnieszka Zakrzewska-Bielawska ${ }^{2, *(D)}$, Beata Glinka ${ }^{3}$ (D) \\ and Aldona Glińska-Neweś ${ }^{4}$ D
}

1 Department of European Integration and International Marketing, Faculty of Management and Production Engineering, Lodz University of Technology, 90-924 Lodz, Poland; magdalena.grebosz@p.lodz.pl

2 Department of Management, Faculty of Management and Production Engineering, Lodz University of Technology, 90-924 Lodz, Poland

3 Department of Entrepreneurship and Management Systems, Faculty of Management, University of Warsaw, 02-678 Warszawa, Poland; b.glinka@uw.edu.pl

4 Department of Organizational Behavior and Marketing, Faculty of Economic Sciences and Management, Nicolaus Copernicus University in Toruń, 87-100 Toruń, Poland; aldona.glinska@umk.pl

* Correspondence: agnieszka.zakrzewska-bielawska@p.lodz.pl

Citation: Grębosz-Krawczyk, M.; Zakrzewska-Bielawska, A.; Glinka, B.; Glińska-Neweś, A. Why Do Consumers Choose Photovoltaic Panels? Identification of the Factors Influencing Consumers' Choice Behavior regarding Photovoltaic Panel Installations. Energies 2021, 14, 2674. https://doi.org/10.3390/ en14092674

Academic Editors: Marek Szarucki and Idiano D'Adamo

Received: 15 March 2021

Accepted: 29 April 2021

Published: 6 May 2021

Publisher's Note: MDPI stays neutral with regard to jurisdictional claims in published maps and institutional affiliations.

Copyright: (c) 2021 by the authors. Licensee MDPI, Basel, Switzerland. This article is an open access article distributed under the terms and conditions of the Creative Commons Attribution (CC BY) license (https:// creativecommons.org/licenses/by/ $4.0 /)$.
Abstract: Renewable energy sources help in decreasing negative environmental impacts and in reducing energy-import dependency. Among all renewable energy segments, photovoltaic panel (PV) installations are one of the fastest-growing. Growing concern about climate change, as well as public policies promoting the development of PV installations, have changed consumers' behaviors and attitudes. This study uses the theory of consumption values to identify factors influencing consumers' choice behavior regarding photovoltaic panel installations. There is little research on consumers' perception of value related to green energy in Poland, especially in the case of photovoltaic panels. We fill this cognitive gap by testing an extended green consumption values model that includes functional, social, emotional, conditional, epistemic, and environmental values. The research was conducted on 250 Polish consumers using a self-administered questionnaire as the research tool. The results of structural equation modeling showed that only functional value and environmental value had a positive impact on consumers' choice behavior toward photovoltaic panels. Photovoltaic panel installations are an important investment for Polish households; however, our research results showed that consumers are able to pay for high quality, environmental protection, and future savings. Individuals' environmentally positive attitude related to environmental concern, environmental knowledge, and responsibility was the strongest determinant of adopting photovoltaic panel installations. New findings concerning Polish consumers' behaviors can provide references for other countries, especially in Central and Eastern Europe. Our results can be useful for marketing managers and policy marketers in developing strategies concerning the successful promotion of the installation of photovoltaic panels in European countries.

Keywords: theory of consumption values; green energy; photovoltaic panels; consumers' behavior; functional value; environmental value

\section{Introduction}

Currently, the market for solar photovoltaic electricity generation is one of the fastestgrowing of all renewable energy sectors [1]. The relatively low costs of solar electricity generation with photovoltaic panel (PV) systems and the potential for further cost reduction have driven the growth of PV installations in recent years. According to Ram et al. [2], solar photovoltaic electricity generation is necessary to achieve deep decarbonization with a high grade of electrification. To meet the Paris Agreement, the power sector is expected to limit 
$\mathrm{CO}_{2}$ emissions by $80 \%$ until 2040 . Consequently, solar photovoltaic electricity generation would have to supply 3518 TWh in 2030 and 7208 TWh in 2040 [3].

Renewable energy sources not only decrease negative environmental impacts, but also reduce energy-import dependency. Consequently, different countries use various incentive systems to encourage the use of renewable energy sources for electricity. By 2050, the European Union (EU) aims to be climate-neutral, which consists of implementation of five dimensions, ranging from energy security and an integrated internal energy market to energy efficiency, climate action, and research and innovation. In the area of the financing of photovoltaic research and development, there are also important differences between countries. Considering the national PV R\&D funding in the EU, it can be stated that the countries' allocation is highly concentrated. Only four countries have provided $83 \%$ of the total accumulated values (Germany, Italy, France, and the Netherlands) [4-6].

Social acceptability is an important determinant of government decisions concerning green energy [7]. We observe the development of new consumer ecological trends. Environmentally conscious consumption is characteristic of modern societies and is increasing among different groups of consumers. Consumers are more and more environmentally aware, and they choose green products more often. Several studies confirm consumers' green behaviors and attitudes toward products representing different sectors, including green energy [7-35], green automotive [36-38], or green building [39-43]. Niamir et al. [22] underlined the importance of behavioral factors in making energy-related decisions and in promoting behavioral solutions for climate-change mitigation in Europe. The area of research concerning consumers' attitudes and behaviors toward green energy, especially solar photovoltaic electricity generation, has been advancing in the academic literature, which has resulted in rapid growth and development of both the theoretical and practical aspects of the research. The previous research concentrated on the issues of environmental-concern factors related to awareness of environmental problems, social influence, environmental attitude, environmental knowledge, and environmental responsibility, as well as government initiatives influencing customers' intentions to adopt green energies [7-16,19,29-35].

In the previous studies concerning households' energy-efficient investments, the consumers' characteristics related to the type of dwelling (house, apartment) and its size, location, and age were identified as important drivers of households' energy-efficient investments $[17,22,23,25,44]$. Home owners and high-income households are more likely to invest in clean-energy technologies than renters and low-income households [17]. In addition, individuals with higher levels of education and those with children were found to be more likely to adopt energy-efficient technologies [24,44-46].

Some researchers also studied factors influencing consumer decision-making concerning photovoltaic panels $[15,18,21,31,47-52]$. This area of research also is still evolving in the academic literature, resulting in rapid growth and development of both the theoretical and practical aspects of the research. However, all elements of the theory of consumption values (TCV) were not considered together in the studies concerning photovoltaic panel adoption, which creates a research gap and confirmation of the problem's novelty. Recognition of customer perception of consumption values in the Polish context can contribute to the theory of consumers' choice behavior regarding photovoltaic panel installations, and can introduce some managerial implications for policymakers and local governments. New findings concerning Polish consumers' behaviors can also provide references for other countries.

The model of consumption values [53] was chosen, taking into account its complexity. Sheth et al. [53] combined the knowledge in the field related to consumers and proposed the consumption value model to determine the factors that lead consumers to buy products. Various disciplines (including economics, sociology, several branches of psychology, and marketing and consumer behavior) have contributed theories and research relevant to these values. This model has been largely applied in scientific research concerning ecofriendly consumer behaviors in recent years [54-65]. 
In Poland, photovoltaic installations are described usually only from a technical perspective. In 2018, Klepacka et al. [51] studied behaviors of Polish rural households, but the study was limited only to functional reasons of consumer behaviors regarding solar-panel installations. Other consumption values were not considered. In this regard, we recognize a cognitive gap in Polish green consumers' behaviors. In light of the above, the following research problem was chosen.

The objective of this paper is to identify the factors influencing consumers' choice behaviors regarding the installation of photovoltaic panels in the context of the theory of consumption values.

The outline of the paper is as follows. The related literature concerning the specificity of the Polish photovoltaic sector, the theory of consumption values (TCV) in the context of green energy consumption, and the hypothesis of the study with a conceptual model are presented in Section 2. Section 3 is dedicated to the presentation of the research methodology. The research results are presented with discussion in Section 4. Finally, the conclusions, theoretical and managerial contributions, and limitations of this study are included in Section 5.

\section{Theoretical Framework}

\subsection{The Specificity of the Polish Photovoltaic Sector}

The energy security of EU27+UK is determined by the relations with their neighbours, especially Norway and Russia. This European Union's dependence is one of the most important stimuli to focus on renewable energy sources. In 2014, the European Commission created "A policy framework for climate and energy in the period from 2020 to 2030" [66,67], in which it highlighted the general direction of energy-policy development for future. The main objectives of climate and energy policies are improved competitiveness, the security of supply, sustainability, and a low-emissive economy. Under the European Energy Policy 2030, the Polish Energy Policy 2050 was formulated.

According to Directive 2009/28/EC of the European Parliament and of the Council of 23 April 2009 on the promotion of the use of energy from renewable sources [68], member states are required to ensure a specific share of energy from renewable sources in gross final energy consumption in 2020. National mandatory general objectives make up the assumed $20 \%$ share of energy from renewable sources in gross final energy consumption in the community. For Poland, this target has been set at 15\% [69]. While many economic reforms have been made, the generating sector was left to its own devices, and due to a lack of investments, that electricity supply in Poland is still ineffective and not secure [67].

Poland-located in Central Europe-experiences strong seasonality, with very good wind and moderate solar resources [70]. However, the Polish energy sector faces a lot of problems related to its infrastructure, as well as economic and political issues. The total energy value of primary energy obtained from renewable sources in Poland in 2019 was 396,498 TJ. Consequently, the gross final consumption of energy from renewable sources in 2015-2019 has increased in recent years, and increased from 325,387 TJ in 2015 to 376,060 TJ in 2019. According to Statistics Poland, in 2019, the energy obtained from renewable sources in Poland came mainly from solid biofuels $(65.56 \%)$, wind farms $(13.72 \%)$, and liquid biofuels $(10.36 \%)$ [69].

The structure of energy consumption from renewable sources in Poland is characterized by a relatively large share $(55 \%)$ of final consumers. This confirms that energy carriers from renewable sources are used less often by industrial (commercial) installations, where as a result of energy transformations, derivative energy carriers (primarily electricity and heat) are produced, which are then delivered to consumers [69].

In Poland, the total installed capacity of photovoltaic sources at the end of 2019 was at the level of almost 1500 MW, and in May 2020 it exceeded 1950 MW. Currently, the largest increase in new installations is observed in the microinstallation segment, which means a high activity of individual and business consumers. The turnover in the photovoltaic 
market increased in 2020 by $25 \%$ compared to the previous year, and exceeded EUR 1 billion [71].

Unlike many countries in Europe, the Polish photovoltaic sector is currently of a very dispersed nature and is based on microinstallations. Different solar support energy programs have been proposed to increase access to renewable energy and offered to residents. The governmental program "My Electricity", which has been operating for a year, and the long-term EU support based on the Regional Operational Programs are pillars of the sustainable development of Polish households, as well as small and medium enterprises. At the end of 2019, microinstallations accounted for over $70 \%$ of the total installed photovoltaic capacity in Poland. The global pandemic has limited the development of this sector to a relatively small extent [71].

\subsection{The Theory of Consumption Values (TCV) in the Context of Green Energy Consumption}

The theory of consumption values (TCV) explains how consumers evaluate and select specific products [53]. The main limitation of the previous models of consumers' behaviors (e.g., Nicosia's model [72]; the Engel, Kollat, and Blackwell model [73]; and the McCarthy, Perreault, and Quester model [74]) is a lack of the complex list of factors that affect consumers' needs and statuses. TCV is based on the existing findings in economics, sociology, psychology, marketing, and consumer behavior, and can be used to assess consumers' choices concerning different product categories, both tangible and intangible [75]. According to Sheth et al. [53], consumer choice decision-making is prejudiced by various consumption values that make contributions in different choice situations. The TCV includes functional value, social value, emotional value, epistemic value, and conditional value, which are independent [57]. Consequently, researchers often evaluate different consumption values as separate constructs during the evaluation of its antecedents and outcomes.

Taking into account the increasing role of the consumers' green attitudes and behaviors, environmental values, also called green consumption values (GCVs), are considered more often in the extended Sheth et al. model [53]. Environmental values are defined as a consumer's tendency to express their environmental protection values in the field of purchase intention and choice behavior [65]. Consumers representing environmental values, such as empathy for nature, personal engagement toward planet protection or eco-centric philosophy, are more committed to the consumption of green products [76-78].

\subsubsection{Functional Value (FV)}

Functional value was developed based on the economic utility theory while including economic rationalism [53]. Sweeney and Soutar [79] described functional value "in terms of the utility derived from the product due to the reduction of its perceived short term and long term costs". Consequently, consumer choice behavior depends on the level of fulfillment of the consumers' utilitarian needs by real product attributes [53]. Consumers accept green products when their needs concerning performance, quality, and convenience are satisfied [80]. Several researchers confirmed that product attributes and quality positively influenced the intention to purchase green products [32-38].

Functional value is related not only to the physical attributes of products, but also refers to the internal and external reference price that the customers evaluate when making a purchase decision [75]. Taking into account the specificity of the photovoltaic panel market, future savings should be included in a functional value dimension. Wang et al. [81] stated that consumers are willing to pay high prices in exchange for high-quality green products. Kaenzig and Wüstenhagen [33] also underlined that environmental attributes of green energy are crucial for green energy consumers.

Sidiras and Koukios [34] confirmed that technical characteristics of solar-energy equipment affect the behaviors of Greek consumers and are determinants to the installation choice. In addition, in China, the purchase of greenhouses is driven by the comprehensive rational factors of consumers [41]. 
Economic intentional variables are strong determinants of the probability of adoption of green power by Dutch households [9]. According to Niamir et al. [22], monetary factors positively affect individual energy-related choices in the Netherlands and Spain. Similar conclusions were formulated by Colasante et al. [21], who confirmed that Italian consumers' choices concerning green energy consumption are largely driven by economic incentives. A positive correlation between income and the probability of investing in green energy technologies also was observed by Mills and Schleich [24,44] and Sardianou and Genoudi [46].

It also has been stated that a higher price can outweigh other considerations and increase a gap in the case of the purchase of green products [82-85]. However, Nunes and Schokker [86] confirmed that socioeconomic variables can positively affect the choice of renewable energy, even in the case of higher prices. It also was stated that price sensitivity has a negative moderation impact on the relationship between environmental responsibility and green consumption intention [87]. Litvine and Wüstenhagen [10] underlined that price is not the only barrier to purchasing green electricity. According to Ecker at al. [88], consumers are willing to pay more for independence, autonomy, self-sufficiency, supply security, and control.

Several utilitarian factors contributing to the use of solar energy by rural residents in Poland were identified by Klepacka et al. [51]. The most important of them were: convenience of use, future savings on energy used to heat space or water, return on investment, and subsidies for panel purchase. Rural households appear to be driven by functional aspects of renewable energy that include a higher degree of independence in energy supply and a reduction of energy costs [35].

Therefore, based on the previous research results concerning household behaviors toward green energy and other sustainable products, the following hypothesis was formulated:

Hypothesis 1 (H1). Functional value has a positive impact on consumers' choice behavior toward photovoltaic panels.

\subsubsection{Social Value (SV)}

Social value is derived from the symbolic importance of a product, often related to the common consumption [53]. All decisions and choices made by the consumer are undertaken in specific sociocultural conditions. Consequently, the need for a sense of belonging and acceptance by the group can significantly influence consumer choices. In several studies, researchers confirmed a positive correlation between social values of consumers and their purchase behavior toward green products $[32,33,35]$. In addition, moral norms have a significant influence on intent to purchase of green products $[37,43]$. Salazar et al. [89] confirmed that peer groups like colleagues, family, and friends may affect the decision to choose environmentally friendly products rather than conventional ones. Similar conclusions were formulated by Lee [90], who stated that peer influence and local environmental involvement affect green purchase behaviors.

The positive impact of investments in green energy on individuals' positive selfimage in local communities engaged in eco-initiatives was confirmed [4,11]. According to Gadenne et al. [91], social norms and community impact are connected with environmental attitudes toward energy savings. Ek and Matti [11] also stated that social norms encourage consumers to invest in proenvironmental activities and impact willingness to pay for reducing the negative impact associated with the establishment of large-scale onshore wind power. Research in Germany also confirmed that intention to use green electricity was most strongly affected by close social contacts [12]. Bollinger and Gillingham [27], Graziano and Gillingham [26], and Jager [28] identified social-interaction effects and social learning processes as important factors driving the adoption of solar PVs. Noll et al. [52] also underlined social-interaction effects as a significant enabling factor in the adoption of solar PVs in the US. 
Contrary to indications in the literature, Mundacaa and Samahita [18] stated that prosocial behavior is not significant in the case of Swedish consumers' behaviors toward solar-energy solutions, and Zailani et al. [36] confirmed that social values were shown to not be a significant factor that influences consumers' willingness to pay for biofuels.

Taking into account the above arguments, the second hypothesis was proposed:

Hypothesis 2 (H2). Social value has a positive impact on consumers' choice behavior toward photovoltaic panels.

\subsubsection{Emotional Value (EV)}

The consumer's behavior depends on many factors, among which there can be distinguished both internal and external stimuli. The category of internal factors includes, among others, emotions that accompany consumers' activities. Emotions play an important role in motivating consumer behaviour. Emotional value influences consumer's choice behavior bases on the emotions that are believed to accompany the use of a product. Emotional value is defined as the perceived utility developed by arousing curiosity, delivering novelty and satisfying the need for knowledge [53].

In opinion of Ecker et al. [88], the implementation of green energy solutions for private homeowners need to consider the motivational aspects of autarky aspiration. Consumers are more likely to accept new technologies when their individual need for independence, autonomy, self-sufficiency, supply security, and control is respected.

According to Hartmann et al. [92] and Yoo et al. [93] emotional values have a significant positive impact on the purchase intention of green products. It was found also that emotional values such as hedonistic values positively affected the purchase behavior of green food products [84,94]. Wüstenhagen and Bilharz [13] also stated that the reason for buying green electricity at a premium is to feel better with themselves.

The following hypothesis was formulated based on the literature review:

Hypothesis 3 (H3). Emotional value has a positive impact on consumers' choice behavior toward photovoltaic panels.

\subsubsection{Conditional Value (CV)}

Conditional value concerns products whose value is strongly related to use in a specific context [53]. Various infrastructural and contextual factors create structural and situational environments that can facilitate or limit proenvironmental behavior [95]. Consequently, when the circumstances create a need, a temporary functional or social value can arise, and changes in consumers' situational variables may affect green-product adoption [29]. Lee [90] found that a consumer's local environmental involvement and consumer exposure to environmental messages (e.g., through media) influenced consumer behaviour. Lin and Huang [96] also concluded that among the main factors influencing consumer choice behavior regarding green products are specific conditions.

The consumer's situation can be changed by government programs and subsidies for the development of green energy $[30,31,48,97]$, as well as discounts and promotions that motivate customers to invest in energy-saving projects [32]. Myojo and Ohashi [48] showed that subsidies are an effective instrument to encourage the greater use of solar panels in Japan, and Mundacaa and Samahita [18] showed that subsidies are significant factors driving the likelihood to adopt solar energy solutions in Sweden.

Sidiras and Koukios [34], Schelly [50], Crago and Chernyakhovskiy [98], Kesari et al. [14], and Baker et al. [94] confirmed that policy-based financial incentives encourage consumers to install solar-energy equipment, because of the relatively high costs of photovoltaic panels. The impact of rules, laws, and regulations on consumers' choices concerning photovoltaic panels can be also mentioned. 
However, Gadenne et al. [91] found that energy-saving behaviors are not in any way affected by government policies or subsidies, and in the opinion of Wolske et al. [49], the financial benefits do not greatly influence the appeal of solar.

Consequently, based on the previous research results, the following hypothesis was formulated:

Hypothesis 4 (H4). Conditional value has a positive impact on consumers' choice behavior toward photovoltaic panels.

\subsubsection{Epistemic Value (EPV)}

Epistemic value is typical for consumers who are curious about something different or want to try something new [53]. Several researchers found a positive correlation between the epistemic value of green products and consumer choice behavior $[62,63,96]$. Lin and Huang [96] concluded that the main factors influencing consumer choice behavior regarding green products include a desire for knowledge and novelty seeking. Consumers choose the green product out of curiosity or to learn about a new product. Suki and Suki [63], Yoo et al. [99], and Rahnama and Rajabpou [100] confirmed the positive impact of epistemic value during the purchase of different categories of green products.

The role of retailers should be underlined in the process of environmentally consumption. Tsarenko et al. [101] confirmed that retailers can develop environmentally conscious consumption if they adopt sustainable business practices. Consequently, promotion of green consumption is one of the ways to minimize the negative environmental impact and increase sustainability [102], because consumers could be persuaded to change their behavior concerning sustainability by being encouraged [103]. In the case of photovoltaic panels, the role of a retailer that provides not only the panels, but also the installation, is crucial. According to Litvine and Wüstenhagen [10], delivery of information targeted at the key determinants influencing the intention to purchase green energy significantly increased the green electricity market share in Switzerland.

Hence, the following hypothesis was developed:

Hypothesis 5 (H5). Epistemic value has a positive impact on consumers' choice behavior toward photovoltaic panels.

\subsubsection{Environmental Value (ENV)}

A positive attitude toward environmental protection is related to the acceptance of certain values that consumers prioritize, taking into account not only themselves but also others. Considering that due to the current concern for the environment, at least a minimum level of proecological behavior is required, such an attitude is necessary to adjust to the groups displaying these positive behaviors. Environmentally friendly attitudes can ultimately shape sustainable consumer behaviour. As a consequence, consumers' activities can have a positive effect on the protection of the natural environment. Consumers who believe that a green product can help solve environmental problems and consumers with high environmental concerns support green products more, and show greater readiness to choose them [96]. According to Yue et al. [87], environmental responsibility has a positive impact on environmental concern, and also has different positive effects on green consumption intention. When consumers choose environmentally friendly products, they feel a sense of accomplishment due to the moral satisfaction of engagement for the environment [86]. Wolske et al. [49] stated that consumer ecofriendly motivations and predispositions are the primary factors driving interest in adopting solar energy. These results also confirmed the findings of Kaiser and Scheuthle [104], who underlined a positive relationship between consumer environmental responsibility and environmentally friendly behavior among Swiss residents, as well as Attaran and Celik [43], who found that American individuals with a high level of environmental responsibility are more likely to show a positive attitude and purchase intention toward green buildings. Mundacaa and Samahita [18] showed that 
environmental awareness plays a positive role in adoption of solar-energy solutions in Sweden. Pandey and Kesari [15] indicated several ecofriendly factors such as environmental attitude, environmental concern, environmental knowledge, perceived environmental behavior, and perceived environmental responsibility that significantly impact decisions to purchase solar-energy products in developing countries.

According to the results of the 2011 OECD survey on household environmental behavior and attitudes, environmental attitudes and beliefs, as manifested in energyconservation practices or membership in an environmental nongovernmental organization, play a relevant role in green-technology adoption [17].

The positive impact of environmental concern on purchase behavior was also confirmed by Yoo et al. [99], Lee [90], Chen and Chang [105], Eze and Nbudisi [106], and Thompson and Tong [107]. Gadenne et al. [91] stated that both intrinsic and extrinsic environmental values are related to environmental attitudes toward energy savings. Arkesteijn and Oerlemans [9] suggested that variables related to environmental behavior in the past were strong determinants of the probability of adoption of green power by Dutch households. According to Niamir et al. [22], a high level of knowledge and awareness about environmental and climate issues influences the level of personal norms and positively affects individual energy-related choices in the Netherlands and Spain. Kesari et al. [14] also confirmed that environmental concern factors, such as social influence, environmental attitude, environmental knowledge, and environmental responsibility, have significant positive influences on customers' intentions to adopt residential PV technology.

According to Wang et al. [81], green trust has a greater effect on green purchase intention in the case of the high perceived price, which can be important in case of photovoltaic panel installations. Consequently, the following hypothesis was proposed:

Hypothesis 6 (H6). Environmental value has a positive impact on consumers' choice behavior toward photovoltaic panels.

Taking together all distinguished consumption values with consumers' choice behavior toward green energy consumption, we built the conceptual model presented in Figure 1.

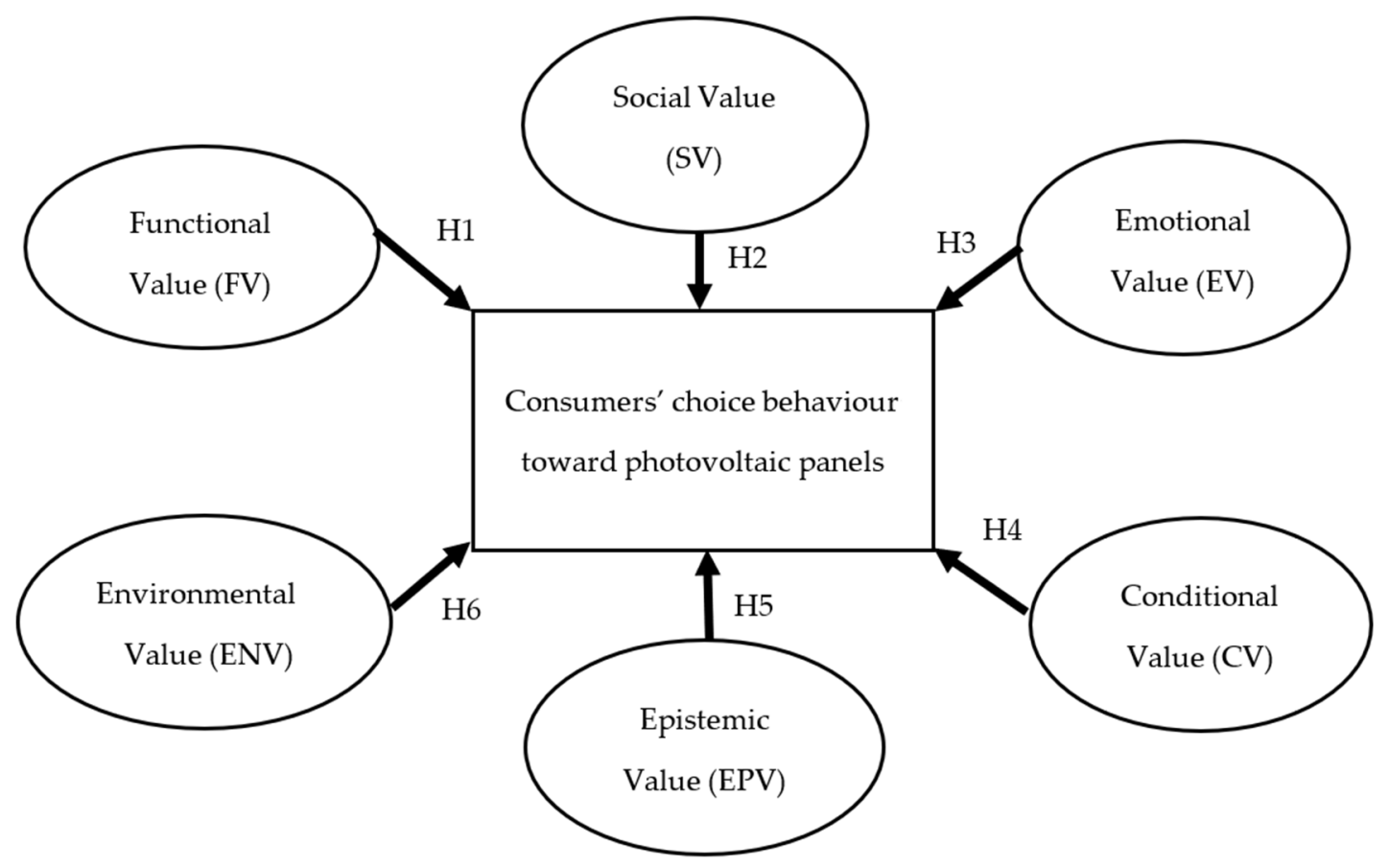

Figure 1. Conceptual model. 


\section{Materials and Methods}

\subsection{Sample and Data Collection}

The survey was conducted in January 2021 on a sample of Polish consumers-owners and co-owners of houses using a self-administered questionnaire. A random selection was used [108]. The survey frame was a database offered by Norstat-the European data collection and market research company. This company has proprietary online panels of 650,000 consumers, which allow researching 18 European countries. For Poland, with a population of 37.9 million people and $78 \%$ Internet penetration, the active panel counted 41,752 consumers over 18 years old, which gave a $38 \%$ average response rate [109].

First, we randomly selected 10 house owners to conduct a pretest. Respondents evaluated the survey according to the content and relevance of the items, and their feedback required minor corrections to improve the readability and intelligibility of the questionnaire. Second, a sample of 1000 consumers was taken from a database of 12,329 consumers who had a house. The data collection resulted in a final sample size of 250 consumers, representing a response rate of $25 \%$, which is acceptable for this type of survey [110]. The respondents were randomly approached during different days and time slots to reduce biases [111]. The main characteristics of respondents are presented in Table 1.

Table 1. Sample characteristics.

\begin{tabular}{|c|c|c|}
\hline Demographic Descriptors & $\mathbf{N}$ & $\%$ \\
\hline \multicolumn{3}{|l|}{ Gender: } \\
\hline Female & 109 & 43.6 \\
\hline Male & 141 & 56.4 \\
\hline \multicolumn{3}{|l|}{ Age: } \\
\hline $18-24$ & 21 & 8.4 \\
\hline $25-34$ & 48 & 19.2 \\
\hline $35-44$ & 59 & 23.6 \\
\hline $45-54$ & 60 & 24.0 \\
\hline $55-64$ & 37 & 14.8 \\
\hline $65+$ & 25 & 10.0 \\
\hline \multicolumn{3}{|l|}{ Education: } \\
\hline Primary & 29 & 11.6 \\
\hline Secondary & 103 & 41.2 \\
\hline Higher & 118 & 47.2 \\
\hline \multicolumn{3}{|l|}{ Place of residence: } \\
\hline Countryside & 114 & 45.6 \\
\hline City up to 50,000 residents & 66 & 26.4 \\
\hline City from 50,000 up to 150,000 residents & 27 & 10.8 \\
\hline City from 150,000 up to 500,000 residents & 29 & 11.6 \\
\hline City over 500,000 residents & 14 & 5.6 \\
\hline \multicolumn{3}{|l|}{ Age of house: } \\
\hline Less than 5 years & 18 & 7.2 \\
\hline $5-10$ & 24 & 9.6 \\
\hline $11-20$ & 56 & 22.4 \\
\hline $20-30$ & 36 & 14.4 \\
\hline Over 30 years & 116 & 46.4 \\
\hline
\end{tabular}

Most of the respondents were males from 35 to 54 years old with a higher education, as well as living in the countryside or small cities with houses over 10 years old.

To test for nonresponse bias, we compared early and late respondents (the first versus the last quartile of respondents) in terms of their mean responses on each variable with a $t$-test [112]. The results showed no significant differences between the two groups. Thus, our results should not be affected by a nonresponse bias. 


\subsection{Measures}

We adopted the consumption value model proposed by Sheth et al. [53] to explore the perception of particular values. The questionnaire consisted of 32 questions, including three types. First, a question related to consumer choice behavior toward photovoltaic panel installations was asked. Respondents could choose one from three possible responses: (1) "Yes, I have installed them"; (2) "Yes, I plan to set them up in the next 4 years"; and (3) "No, I have not installed them and I am not going to do it". We explained to respondents that photovoltaic panels convert the energy of solar radiation into electricity.

Second, we proposed 25 items measuring the functional, social, emotional, conditional, epistemic, and environmental values, respectively. We used a five-point Likert scale, with $1=$ strongly disagree and $5=$ strongly agree. The Likert scale was selected because of the advantage of allowing questioning without systematic errors [113]. An initial list of measurement items was developed based on a review of literature related to functional value, social value, emotional value, epistemic value, conditional value, and environmental value. The extended Sheth et al. model [53] has been used in some research concerning consumers' attitudes and behaviors toward green products. Consequently, different researchers developed the initial list of measurement created by Sheth et al. [53], taking into account the specificity of particular markets, new consumer trends, technological changes, and climatic conditions. As a result, items adapted to specific markets and groups of consumers were created. During development of the questionnaire, several studies concerning green consumers' attitudes and behaviors were considered. The items created by Sweeney and Soutar [79], Yoo et al. [99], Arvola et al. [114], Dholakia [115], Hirschman [116], Tarrant and Cordell [117], Barr and Gilg [42], Sangroya and Nayak [19], and Zailani et al. [36] were finally selected. Taking into account the specificity of the PV panel market, the chosen items were analyzed and modified in cooperation with a panel of experts comprising five professors from the marketing and management fields and five representatives of companies offering photovoltaic panel installations.

Third, demographic characteristics of respondents including gender, age, level of education, place of residence, and age of house were used. The multiple-choice response scale was applied for those characteristics.

\subsection{Data Analysis}

Since the scales for different consumption values used in our study were established in the literature, we assessed the scale validity and reliability through performing a confirmatory factor analysis (CFA) and Cronbach's alpha, respectively. We employed a rigorous process advocated by Gerbing and Anderson [118] and Hair et al. [119]. To determine the impact of particular consumption values on purchase intentions toward photovoltaic panels and to test the hypotheses, we performed a structural equation modeling (SEM) [120]. To conduct various statistical tests, we employed two statistical packages: Statistica and Amos.

\section{Results}

\subsection{Scale Validation and Reliability Analysis}

To assess the measurement validity, a confirmatory factor analysis using a maximum likelihood estimation [121] was performed. A CFA is used to test whether the measures of a construct are consistent with a researcher's understanding of the construct's nature, and to test whether the data fit a hypothesized measurement model [122]. We tested the scale convergent validity, including standardized loadings higher than 0.5 and average variance extracted (AVE) higher than 0.5 [119]. For the discriminant validity analysis, we checked whether the square roots of the AVE values were greater than all individual correlations [123].

When conducting the CFA, some items were dropped because of the undesirable values of standardized loadings associated with them (i.e., the values were lower than 0.5) [119]. Thus, we were unable to confirm the convergent validity of two consumption values: conditional value and epistemic value. 
The CFA results revealed a good fit $\left(\chi^{2} / d f=1.908\right.$; goodness of fit index $(\mathrm{GFI})=0.899$; Tucker-Lewis index $(\mathrm{TLI})=0.897$; comparative fit index $(\mathrm{CFI})=0.900$; and the root mean square error of approximation $($ RMSEA $)=0.089$ ). The goodness of fit was within the acceptable range, and indicated a moderate fit [119]. All $t$-tests of the observed variables were significant at the 0.001 level.

The reliability analysis was conducted by calculating Cronbach's $\alpha$ and composite reliability (CR). Similarly, except for the conditional value and epistemic value, the results showed good reliability with Cronbach's $\alpha$, and CR surpassed the threshold value of 0.7 [123].

Table 2 summarizes the results of the convergent validity assessed through factor loadings and AVE, as well as reliability expressed by Cronbach's alpha and CR. The discriminant validity, mean, and standard deviation are shown in Table 3.

All statistics (loads, AVE, Cronbach's alpha, CR) were on an acceptable level. Thus, good internal consistency among the items within four consumption values (the functional, social, emotional, and environmental) was confirmed. The environmental value scored highest, with a mean value of 4.068, followed by emotional (3.824), social (3.612), and functional (3.600). All correlations between variables were significant $(p<0.01)$ and positive, and the square roots of AVE for a particular variable confirmed the scale discriminant validity.

Table 2. Factor loadings, convergent validity, and reliability of variables *.

\begin{tabular}{|c|c|c|c|c|}
\hline & Variable/Items & Loading & $\begin{array}{l}\text { Convergent } \\
\text { Validity }\end{array}$ & Reliability \\
\hline \multicolumn{5}{|c|}{ Functional Value (FV) $[19,36,79]$} \\
\hline FV1 & $\begin{array}{l}\text { The photovoltaic panels available on the market are of } \\
\text { good quality }\end{array}$ & 0.912 & \multirow{6}{*}{$\mathrm{AVE}=0.535$} & \multirow{6}{*}{$\begin{array}{c}\alpha \text { Cron. }=0.865 \\
C R=0.870\end{array}$} \\
\hline FV2 & $\begin{array}{l}\text { The photovoltaic panels available in the market } \\
\text { are well made }\end{array}$ & 0.864 & & \\
\hline FV3 & The photovoltaic panels perform consistently & 0.695 & & \\
\hline FV4 & The photovoltaic panels are reasonably priced & 0.605 & & \\
\hline FV5 & Using photovoltaic panels offers value for money & 0.643 & & \\
\hline FV6 & Using photovoltaic panels offers future savings & 0.675 & & \\
\hline \multicolumn{5}{|c|}{ Social Value $(S V)[36,79,99]$} \\
\hline SV1 & $\begin{array}{c}\text { Installation of photovoltaic panels improves the image } \\
\text { of its owner }\end{array}$ & 0.787 & \multirow{5}{*}{$\mathrm{AVE}=0.563$} & \multirow{5}{*}{$\begin{array}{l}\alpha \text { Cron. }=0.865 \\
C R=0.866\end{array}$} \\
\hline SV2 & $\begin{array}{l}\text { Installation of photovoltaic panels makes a good } \\
\text { impression on other people }\end{array}$ & 0.719 & & \\
\hline SV3 & $\begin{array}{c}\text { Installation of photovoltaic panels gives its owner } \\
\text { social approval }\end{array}$ & 0.722 & & \\
\hline SV4 & $\begin{array}{l}\text { Installation of photovoltaic panels reflects } \\
\text { environmental knowledge and awareness }\end{array}$ & 0.765 & & \\
\hline SV5 & $\begin{array}{l}\text { Installation of photovoltaic panels reflects concern for } \\
\text { the environment }\end{array}$ & 0.758 & & \\
\hline \multicolumn{5}{|c|}{ Emotional Value (EV) $[99,114]$} \\
\hline EV1 & $\begin{array}{l}\text { Installation of photovoltaic panels instead of } \\
\text { conventional energy sources would feel like making a } \\
\text { personal contribution to good for society }\end{array}$ & 0.721 & \multirow{3}{*}{$\mathrm{AVE}=0.601$} & \multirow{3}{*}{$\begin{array}{c}\alpha \text { Cron. }=0.811 \\
C R=0.817\end{array}$} \\
\hline EV2 & $\begin{array}{l}\text { Installation of photovoltaic panels instead of } \\
\text { conventional energy sources seems to be morally right } \\
\text { Installation of photovoltaic panels instead of }\end{array}$ & 0.864 & & \\
\hline EV3 & $\begin{array}{l}\text { conventional energy sources makes/would make me } \\
\text { feel like a better person }\end{array}$ & 0.732 & & \\
\hline \multicolumn{5}{|c|}{ Environmental Value (ENV) [42,117] } \\
\hline ENV1 & $\begin{array}{l}\text { I would install/installed the photovoltaic panels for } \\
\text { ecological reasons }\end{array}$ & 0.714 & \multirow{5}{*}{$\mathrm{AVE}=0.548$} & \multirow{5}{*}{$\begin{array}{l}\alpha \text { Cron. }=0.856 \\
C R=0.858\end{array}$} \\
\hline ENV2 & $\begin{array}{c}\text { Photovoltaic panels help reducing } \\
\text { environment pollution }\end{array}$ & 0.755 & & \\
\hline ENV3 & $\begin{array}{l}\text { I am willing to commit myself to } \\
\text { environmental protection }\end{array}$ & 0.737 & & \\
\hline ENV4 & $\begin{array}{l}\text { I believe personal responsibility for environmental } \\
\text { problems is important }\end{array}$ & 0.715 & & \\
\hline ENV5 & $\begin{array}{l}\text { I believe the moral obligation to help the environment } \\
\text { is important. }\end{array}$ & 0.778 & & \\
\hline
\end{tabular}

* Based on the results of the CFA and reliability analysis, the conditional value and epistemic value were not extracted. 
Table 3. Descriptive statistics, correlations between variables, and discriminant validity.

\begin{tabular}{ccccc}
\hline Variables & FV & SV & EV & ENV \\
\hline FV & $\mathbf{0 . 7 3 1}$ & & & \\
SV & $0.577^{* *}$ & $\mathbf{0 . 7 5 1}$ & & \\
EV & $0.613^{* *}$ & $0.660^{* *}$ & $\mathbf{0 . 7 7 5}$ & $\mathbf{0 . 7 4 0}$ \\
ENV & $0.534^{* *}$ & $0.676^{* *}$ & $0.700^{* *}$ & 4.07 \\
\hline Mean & 3.60 & 3.61 & 3.82 & 0.82 \\
s.d. & 0.74 & 0.83 & 0.89 &
\end{tabular}

Note. $\mathrm{N}=250$; s.d.—-standard deviation; correlation was statistically significant at $p<0.01\left({ }^{* *}\right)$. The diagonal values (in bold) present the square roots of AVE.

To test for potential common methods bias, we conducted Harman's one-factor test and a confirmatory factor analysis. As Podsakoff et al. [124] suggested, common method variance is not a problem if items load on multiple factors and one factor does not account for most of the covariance. Our analyses, i.e., an unrotated principal component factor analysis, principal component analysis with varimax rotation, and principal axis analysis with varimax rotation, revealed the presence of four distinct factors with an eigenvalue greater than 1.0, rather than a single factor. Our four factors together accounted for $63.72 \%$ of the total variance, and the largest factor did not account for a majority of the variance (25.4\%). Thus, no general factor was apparent.

Additionally, the CFA results showed that the single-factor model did not fit the data well. Thus, it was indicated that common method bias was not of great concern, was effectively controlled for in the analysis, and thus was unlikely to confound the interpretations of the study's results.

\subsection{The Structural Equation Model and Hypothesis Testing}

We tested our conceptual model and hypotheses using structural equation modeling (SEM) with a maximum likelihood (ML) estimation and covariance matrix as data input. The ML estimation method is often indicated as well suited to theory testing and development [118]. The SEM model helps in establishing the causal relationships between the variables. Standardized residual values were less than 0.05 and suggested a good model fit. Similarly, the statistics of the model (i.e., $\chi^{2} / d f=0.568$; RMSEA $=0.071$; GFI $=0.901$; $\mathrm{CFI}=0.908 ; \mathrm{TLI}=0.905$ ) proved its good fit [120]. The hypotheses were evaluated using the standardized $b$ values, $t$-values, and the corresponding significance level. The results of the structural equation modeling are presented in Table 4 and Figure 2.

Table 4. Results of the structural equation modeling.

\begin{tabular}{clcccccc}
\hline $\begin{array}{c}\text { Independent } \\
\text { Variable }\end{array}$ & & Dependent Variable & $\boldsymbol{B}$ & SE & $\boldsymbol{t}$ Value & $\boldsymbol{p}$ Value & Results \\
\hline FV & $\rightarrow$ & Consumer choice (I & 0.149 & 0.044 & 3.412 & $0.000^{* * *}$ & H1 confirmed \\
SV & $\rightarrow$ & have/I plan to install & -0.029 & 0.040 & -0.719 & 0.472 & H2 not confirmed \\
EV & $\rightarrow$ & photovoltaic panels) & -0.069 & 0.043 & -1.591 & 0.112 & H3 not confirmed \\
ENV & $\rightarrow$ & & 0.052 & 3.661 & $0.000^{* * *}$ & H6 confirmed \\
\hline
\end{tabular}

Note. $\mathrm{N}=250$; significance level at $p<0.01{ }^{(* * *)} ; \mathrm{b} B$ - unstandardized path coefficient; SE—standard error.

Of our six formulated hypotheses, only two received support from the data. Hypothesis $\mathrm{H1}$, considering a positive impact of functional value on consumers' choice behavior toward photovoltaic panels, was confirmed $(\beta=0.215 ; \mathrm{t}=3.412 ; p<0.001)$; and hypothesis H6, considering a positive impact of environmental value on consumers' choice behavior toward photovoltaic panels $(\beta=0.247 ; \mathrm{t}=3.661 ; p<0.001)$ also was confirmed. From these two values, the environmental value had the greater impact. 


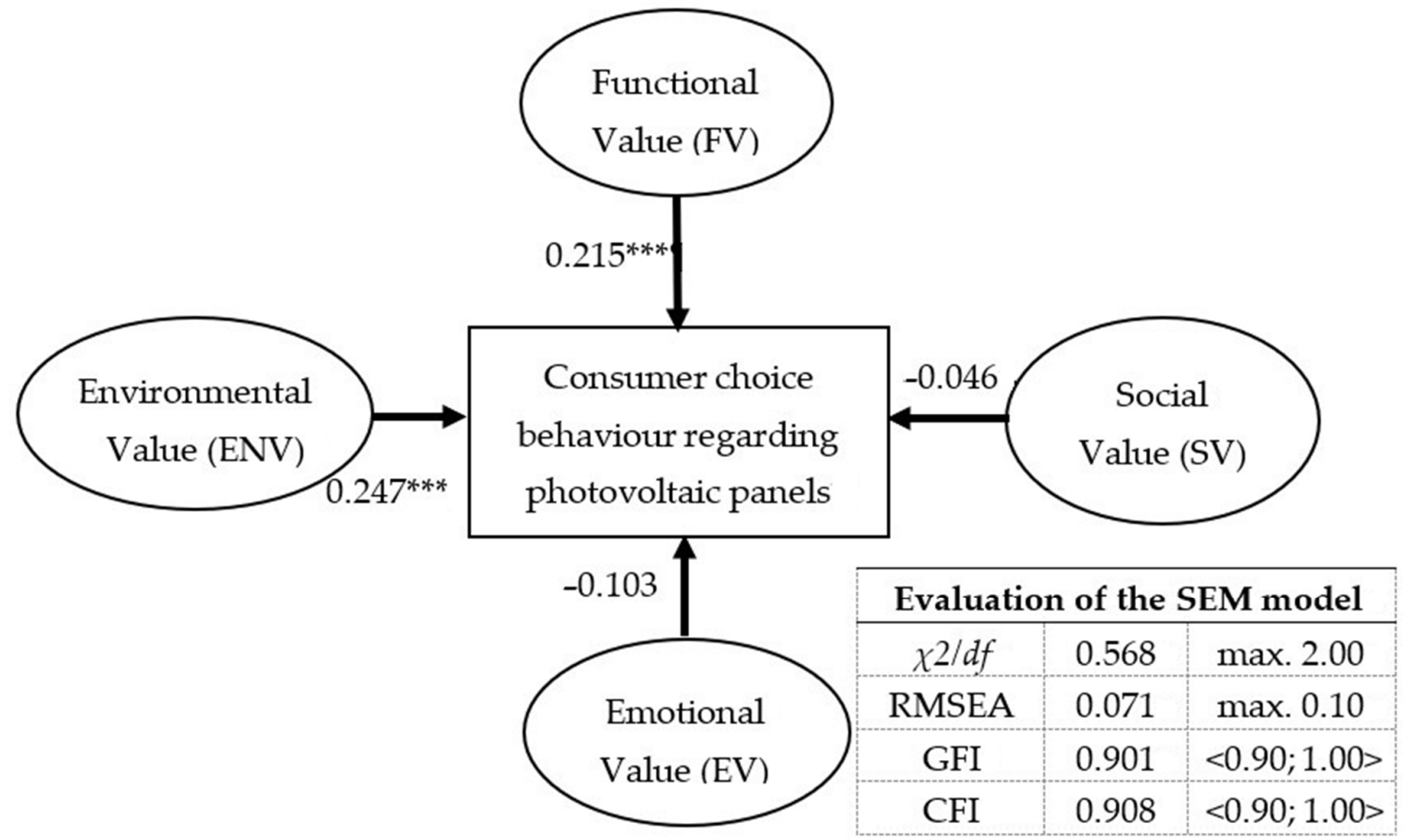

Figure 2. SEM model. Note: the SEM model differed from the conceptual model (Figure 1) in that it tested only 4 consumption values (functional, social, emotional, and environmental). The conditional value and epistemic value were not extracted through the CFA, and thus were not tested.

Hypotheses $\mathrm{H} 2$ and $\mathrm{H} 3$ were falsified. The impact of social value and emotional value were not statistically significant $(p>0.05)$. Moreover, the impact of both was negative.

We were not able to test hypotheses $\mathrm{H} 4$ and $\mathrm{H} 5$ because we could not build the latent variable for the conditional value needed for hypothesis $\mathrm{H} 4$ or the latent variable for the epistemic value needed for hypothesis $\mathrm{H} 5$.

Taking into account the control variables (respondents' gender, level of education, place of residence, and age of house), more dependencies appeared, such as:

a. For women, an additional value influencing their choice behavior toward photovoltaic panels was the emotional value, but its impact was negative $(\beta=-0.240$; $\mathrm{t}=-2.503 ; p<0.05$;

b. For people with a higher education, only environmental value influenced their choice behavior toward green energy $(\beta=0.265 ; t=2.738 ; p<0.05)$;

c. For people living in the countryside, the functional value impacted their choice behavior toward green energy $(\beta=0.221 ; t=2.338 ; p<0.05)$; while for people living in cities, the value that had an impact on this choice behavior was the environmental value $(\beta=0.265 ; \mathrm{t}=2.737 ; p<0.01)$;

d. For people with a house less than 30 years old, the choice behavior toward photovoltaic panels was influenced by the functional value $(\beta=0.289 ; \mathrm{t}=3.403 ; p<0.01)$, and in a negative way, the emotional value $(\beta=-0.198 ; \mathrm{t}=-2.233 ; p<0.05)$; while for people with a house over 30 years old, the only significant value that influenced their choice behavior was the environmental value $(\beta=0.375 ; \mathrm{t}=3.808 ; p<0.01)$.

These research results confirmed the previous research results of Mahaptra and Gustavsson [45], Mills and Schleich [24,44], Michelsen and Madlener [25], and Sardianou and Genoudi [46] concerning the impact of education level on the motivation of adoption of energy-efficient technologies. 


\section{Discussion}

Our study made it possible to indicate factors influencing the choice of photovoltaic panel installations in the context of the theory of consumption values. Research results showed that functional and environmental values had the greatest impact on green energy consumption. This was partially consistent with the results of other scholars. It confirmed the results of the research of Zhai and Williams [47], Kesari et al. [14], and Ecker et al. [88], who stated that other issues such as maintenance requirements and environmental concerns were important in the adoption of renewable energy technologies, especially photovoltaic panels.

Environmental knowledge and environmental awareness influence green purchase behaviors. Research results showed that environmental value is a significant factor in determining intentions to purchase photovoltaic panels. These research results were consistent with results of the OECD survey on household environmental behaviors and attitudes conducted in 2011 [17]. Niamir et al. [22] and Mundaca and Samahita [18] also showed that environmental awareness played a positive role in adoption of green energy solutions. The importance of environmental value was confirmed by Wolske et al. [49], who stated that ecofriendly motivations and predispositions of consumers are the most important factors stimulating the adoption of solar energy. Pandey and Kesari [15] stated that individual ecological attitude significantly impacted the purchase decision of solar-energy products in developing countries. Attaran and Celik [43] and Kaiser and Scheuthle [104] also highlighted the impact of consumer environmental responsibility on ecofriendly behavior. Similar conclusions were formulated by Gadenne et al. [91] and Arkesteijn and Oerlemans [9]. Environmentally positive attitudes related to environmental concern, environmental knowledge, and environmental responsibility is one of the strongest determinants of the solar photovoltaic installations' adoption.

The research results also showed the impact of functional value on consumer choice behavior regarding solar energy. It was confirmed that for the majority of respondents, attributes of photovoltaic panels were related to green purchase behavior, and this was consistent with the results of Kaenzig and Wüstenhagen [33] in Switzerland, as well as those of Sidiras and Koukios [34] in Greece. Photovoltaic panel installations are a huge investment for Polish households. However, taking into account the research results, we can state that consumers are able to pay for high quality, environmental protection, and future savings. This confirms the findings of Nunes and Schokker [86] and Wang et al. [81], who stated high prices are accepted in exchange for high-quality green products, as well as the findings of Ecker et al. [88], who stated that consumers accept new green energy solutions for satisfaction of their individual need for independence, autonomy, self-sufficiency, supply security, and control. Several functional factors influencing the choice of solar energy by rural residents in Poland — such as a higher degree of independence in energy supply and a reduction of energy costs—-were also identified by Klepacka et al. [51].

The results did not confirm the impact of conditional value on photovoltaic panel installations. This was consistent with the findings of Gadenne et al. [91] and Wolske et al. [49], who found that energy-saving behaviors are not in any way affected by government policies or subsidies, and do not greatly influence the appeal of solar energy. Subsidies for Polish households are currently planned, but it is not known when the new program will be implemented. As a result, Polish consumers do not know if and on what terms it will be possible to receive subsidies. This may limit their enthusiasm for solar panels. These research results did not confirm the findings from Western and North Europe, where the monetary factors positively affect individual energy-related choices $[18,21,22,44,46]$.

Similar results were obtained in the case of epistemic value. This may be the result of insufficient involvement of producers of photovoltaic panels, as well as governmental and nongovernmental organizations, in the environmental consumption process. Polish consumers lack information about the importance and possibilities of using solar energy. This is due to the insufficient promotion of sustainable practices. It should be emphasized that promoting information concerning green energy is one of the ways to reduce pol- 
lution and protect the environment by convincing consumers to change their behaviors to become more ecological. This confirms the theses of Litvine and Wüstenhagen [10], Tsarenko et al. [101], and Liobikienè and Bernatonienè [102], and the experiences in Switzerland [33].

It was stated that social value is not a factor influencing sustainable consumption behavior toward adopting photovoltaic panel installations. Similar conclusions were formulated by Mundaca and Samahita [18], who stated that prosocial behavior is not significant in the adoption of PV panels, as well as Zailani et al. [36] for purchase intention toward biofuels.

The research results also showed a lack of the significant impact of epistemic and emotional value on solar-energy adoption. Taking into account the monetary value of an investment, consumers do not choose the photovoltaic panels based on emotions or curiosity, but instead on functional and proenvironmental attitudes.

\section{Conclusions}

The implementation of energy-saving and renewable energy technologies by households can significantly reduce the negative emissions related to electricity generation. The relatively low costs of solar-electricity generation with photovoltaic systems and the potential for further cost reduction will drive the growth of photovoltaic panel installations in the coming decades. In the opinion of Breyer et al. [70], solar photovoltaic panels will evolve as the most important power technology, accompanied by wind energy and hydropower. Growing concern about climate change, as well as public policies promoting the development of renewable energy installations, has initiated an important transformation in consumers' behaviors and attitudes.

The present study sought to answer the challenging questions regarding the issues in the studies concerning photovoltaic panel adoption.

The results of the study contribute to the theory of consumer values and sustainable consumer behaviors. Testing the most extended model of consumption values among Polish consumers, we identified factors influencing consumers' behaviors toward green energy in this cultural context. For Polish consumers, only two values (functional and environmental) were important in the decision to purchase photovoltaic panels. On the other hand, our results showed awareness and attitudes toward green energy in Polish society.

Regarding managerial implications, our results can be beneficial for policymakers in developing strategies concerning the successful promotion of the installation of photovoltaic panels in European countries. To make the green-energy business sustainable, consumers should accept, purchase, and use green energy, such as photovoltaic panels. This requires the formulation of effective policies and marketing strategies that motivate consumers to use green energy. Recognition of customer perception of values in the Polish context allows policymakers and marketing managers to create policies and strategies more convincing for the Polish market.

Our study had a few limitations that created further directions for the research. First, our sample was relatively small, therefore further research should be conducted on a large, representative sample. Second, we limited the research to Polish consumers, so an interesting direction of further research could be a comparative analysis of the influence of consumption values on consumers' behaviors toward green energy in different European countries. Third, we tested consumers' behaviors toward only one source of green energy, i.e., photovoltaic panels. That is why another exciting direction of research could be testing the impact of consumption values on consumers' behaviors toward other sources of green energy, such as biofuels, wind farms, biogas, and hydro- or geothermal energy. 
Author Contributions: Conceptualization, M.G.-K., A.Z.-B., B.G. and A.G.-N.; methodology, M.G.-K. and A.Z.-B.; validation, A.Z.-B. and A.G.-N.; formal analysis, A.Z.-B. and B.G.; investigation, M.G.-K.; data curation, A.Z.-B.; writing-original draft preparation, A.Z.-B., B.G. and A.G.-N.; writingreview and editing, M.G.-K. and A.Z.-B. All authors have read and agreed to the published version of the manuscript.

Funding: This research received no external funding.

Institutional Review Board Statement: Not applicable.

Informed Consent Statement: Not applicable.

Data Availability Statement: The data presented in this study are available on request from the corresponding author.

Conflicts of Interest: The authors declare no conflict of interest.

\section{References}

1. Renewable Energy Statistics. Available online: https://ec.europa.eu/eurostat/statistics-explained/index.php/Renewable_ energy_statistics (accessed on 10 December 2020).

2. Ram, M.; Bogdanov, D.; Aghahosseini, A.; Gulagi, A.; Oyewo, A.; Child, M.; Caldera, U.; Sadovskaia, K.; Farfan, J.; Barbosa, L. Global Energy System Based on 100\% Renewable Energy-Power, Heat, Transport and Desalination Sectors; Lappeenranta University of Technology and Energy Watch Group: Berlin, Germany, 2019.

3. Jäger-Waldau, A. Snapshot of Photovoltaics-February 2020. Energies 2020, 13, 930. [CrossRef]

4. Ozcan, M. Assessment of renewable energy incentive system from investors' perspective. Renew. Energy 2014, 71, 425-432. [CrossRef]

5. Zhang, H.L.; Van Gerven, T.; Baeyens, J.; Degrève, J. Photovoltaics: Reviewing the European Feed-in-Tariffs and Changing PV Efficiencies and Costs. Sci. World J. 2014, 2014, 404913. [CrossRef] [PubMed]

6. De Negri, J.F.; Pezzutto, S.; Gantioler, S.; Moser, D.; Sparber, W. A Comprehensive Analysis of Public and Private Funding for Photovoltaics Research and Development in the European Union, Norway, and Turkey. Energies 2020, 13, 2743. [CrossRef]

7. Bronfman, N.C.; Jiménez, R.B.; Arévalo, P.C.; Cifuentes, L.A. Understanding social acceptance of electricity generation sources. Energy Policy 2012, 46, 246-252. [CrossRef]

8. Hartmann, P.; Apaolaza-Ibáñez, V. Consumer attitude and purchase intention toward green energy brands: The roles of psychological benefits and environmental concern. J. Bus. Res. 2012, 65, 1254-1263. [CrossRef]

9. Arkesteijn, K.; Oerlemans, L. The early adoption of green power by Dutch households: An empirical exploration of factors influencing the early adoption of green electricity for domestic purposes. Energy Policy 2005, 33, 183-196. [CrossRef]

10. Litvine, D.; Wüstenhagen, R. Helping "light green" consumers walk the talk: Results of a behavioural intervention survey in the Swiss electricity market. Ecol. Econ. 2011, 70, 462-474. [CrossRef]

11. Ek, K.; Matti, S. Valuing the local impacts of a large scale wind power establishment in northern Sweden: Public and private preferences toward economic, environmental and sociocultural values. J. Environ. Plan. Manag. 2015, 58, 1327-1345. [CrossRef]

12. Gerpott, T.J.; Mahmudova, I. Determinants of price mark-up tolerance for green electricity-lessons for environmental marketing strategies from a study of residential electricity customers in Germany. Bus. Strat. Environ. 2009, 19, 304-318. [CrossRef]

13. Wüstenhagen, R.; Bilharz, M. Green energy market development in Germany: Effective public policy and emerging customer demand. Energy Policy 2006, 34, 1681-1696. [CrossRef]

14. Kesari, B.; Atulkar, S.; Pandey, S. Consumer Purchasing Behaviour towards Eco-Environment Residential Photovoltaic Solar Lighting Systems. Glob. Bus. Rev. 2021, 22, 236-254. [CrossRef]

15. Pandey, S.; Kesari, B. Consumer purchase behaviour of solar equipments: Paradigm shift towards the ecological motivation among rural working consumers in developing countries. J. Adv. Res. Dyn. Control Syst. 2018, 10, 363-375.

16. Sigrin, B.; Pless, J.; Drury, E. Diffusion into new markets: Evolving customer segments in the solar photovoltaics market. Environ. Res. Lett. 2015, 10, 1-8. [CrossRef]

17. Ameli, N.; Brandt, N. Determinants of households' investment in energy efficiency and renewables: Evidence from the OECD survey on household environmental behaviour and attitudes. Environ. Res. Lett. 2015, 10, 044015. [CrossRef]

18. Mundaca, L.; Samahita, M. What drives home solar PV uptake? Subsidies, peer effects and visibility in Sweden. Energy Res. Soc. Sci. 2020, 60, 101319. [CrossRef]

19. Sangroya, D.; Nayak, J.K. Factors influencing buying behaviour of green energy consumer. J. Clean. Prod. 2017, 151, 393-405. [CrossRef]

20. Van der Kam, M.; Meelen, A.; van Sark, W.; Alkemade, F. Diffusion of solar photovoltaic systems and electric vehicles among Dutch consumers: Implications for the energy transition. Energy Res. Soc. Sci. 2018, 46, 68-85. [CrossRef]

21. Colasante, A.; D'Adamo, I.; Morone, P. Nudging for the increased adoption of solar energy? Evidence from a survey in Italy. Energy Res. Soc. Sci. 2021, 74, 101978. [CrossRef] 
22. Niamir, L.; Ivanova, O.; Filatova, T.; Voinov, A.; Bressers, H. Demand-side solutions for climate mitigation: Bottom-up drivers of household energy behavior change in the Netherlands and Spain. Energy Res. Soc. Sci. 2020, 62, 101356. [CrossRef]

23. Dubois, G.; Sovacool, B.; Aall, C.; Nilsson, M.; Barbier, C.; Herrmann, A.; Bruyère, S.; Andersson, C.; Skold, B.; Nadaud, F.; et al. It starts at home? Climate policies targeting household consumption and behavioral decisions are key to low-carbon futures. Energy Res. Soc. Sci. 2019, 52, 144-158. [CrossRef]

24. Mills, B.F.; Schleich, J. Profits or preferences? Assessing the adoption of residential solar thermal technologies. Energy Policy 2009, 37, 4145-4154. [CrossRef]

25. Michelsen, C.C.; Madlener, R. Homeowners' preferences for adopting innovative residential heating systems: A discrete choice analysis for Germany. Energy Econ. 2012, 34, 1271-1283. [CrossRef]

26. Graziano, M.; Gillingham, K. Spatial patterns of solar photovoltaic system adoption: The influence of neighbors and the built environmentz. J. Econ. Geogr. 2015, 15, 815-839. [CrossRef]

27. Bollinger, B.; Gillingham, K. Peer Effects in the Diffusion of Solar Photovoltaic Panels. Mark. Sci. 2012, 31, 900-912. [CrossRef]

28. Jager, W. Stimulating the diffusion of photovoltaic systems: A behavioural perspective. Energy Policy 2006, 34, 1935-1943. [CrossRef]

29. Niemeyer, S. Consumer voices: Adoption of residential energy-efficient practices. Int. J. Consum. Stud. 2010, 34, 140-145. [CrossRef]

30. Tsoutsos, T.; Drandaki, M.; Frantzeskaki, N.; Iosifidis, E.; Kiosses, I. Sustainable energy planning by using multi-criteria analysis application in the island of Crete. Energy Policy 2009, 37, 1587-1600. [CrossRef]

31. Sovacool, B.K.; Ratan, P.L. Conceptualizing the acceptance of wind and solar electricity. Renew. Sustain. Energy Rev. 2012, 16, 5268-5279. [CrossRef]

32. Caird, S.; Roy, R.; Herring, H. Improving the energy performance of UK households: Results from surveys of consumer adoption and use of low- and zero-carbon technologies. Energy Effic. 2008, 1, 149-166. [CrossRef]

33. Kaenzig, J.; Wüstenhagen, R. Understanding the Green Energy Consumer. Mark. Rev. St. Gallen 2008, 25, 12-16. [CrossRef]

34. Sidiras, D.K.; Koukios, E.G. Solar systems diffusion in local markets. Energy Policy 2004, 32, 2007-2018. [CrossRef]

35. Klepacka, A.M. Significance of renewable energy sources in sustainable development. Ann. Pol. Assoc. Agric. Agribus. Econ. 2019, XXI, 55-64. [CrossRef]

36. Zailani, S.; Iranmanesh, M.; Hyun, S.S.; Ali, M.H. Applying the Theory of Consumption Values to Explain Drivers' Willingness to Pay for Biofuels. Sustainability 2019, 11, 668. [CrossRef]

37. Chowdhury, M.; Salam, K.; Tay, R. Consumer preferences and policy implications for the green car market. Mark. Intell. Plan. 2016, 34, 810-827. [CrossRef]

38. Jaderná, E.; Přikrylová, J. Green solutions in automotive industry. Mark. Sci. Inspir. 2018, 13, $2-11$.

39. Zuo, J.; Zhao, Z.-Y. Green building research-current status and future agenda: A review. Renew. Sustain. Energy Rev. 2014, 30, 271-281. [CrossRef]

40. Alsulaili, A.D.; Al-Matrouk, M.F.; Al-Baghli, R.A.; Al-Enezi, A.F. Environmental and economic benefits of applying green building concepts in Kuwait. Environ. Dev. Sustain. 2019, 22, 3371-3387. [CrossRef]

41. Sang, P.; Yao, H.; Zhang, L.; Wang, S.; Wang, Y.; Liu, J. Influencing factors of consumers' willingness to purchase green housing: A survey from Shandong Province, China. Environ. Dev. Sustain. 2019, 22, 4267-4287. [CrossRef]

42. Barr, S.; Gilg, A. Sustainable lifestyles: Framing environmental action in and around the home. Geoforum 2006, 37, 906-920. [CrossRef]

43. Attaran, S.; Celik, B.G. Students' environmental responsibility and their willingness to pay for green buildings. Int. J. Sustain. High. Educ. 2015, 16, 327-340. [CrossRef]

44. Mills, B.; Schleich, J. Residential energy-efficient technology adoption, energy conservation, knowledge, and attitudes: An analysis of European countries. Energy Policy 2012, 49, 616-628. [CrossRef]

45. Mahapatra, K.; Gustavsson, L. An adopter-centric approach to analyze the diffusion patterns of innovative residential heating systems in Sweden. Energy Policy 2008, 36, 577-590. [CrossRef]

46. Sardianou, E.; Genoudi, P. Which factors affect the willingness of consumers to adopt renewable energies? Renew. Energy 2013, 57, 1-4. [CrossRef]

47. Zhai, P.; Williams, E.D. Analyzing consumer acceptance of photovoltaics (PV) using fuzzy logic model. Renew. Energy 2012, 41, 350-357. [CrossRef]

48. Myojo, S.; Ohashi, H. Effects of consumer subsidies for renewable energy on industry growth and social welfare: The case of solar photovoltaic systems in Japan. J. Jpn. Int. Econ. 2018, 48, 55-67. [CrossRef]

49. Wolske, K.S.; Todd, A.; Rossol, M.; McCall, J.; Sigrin, B. Accelerating demand for residential solar photovoltaics: Can simple framing strategies increase consumer interest? Glob. Environ. Chang. 2018, 53, 68-77. [CrossRef]

50. Schelly, C. Residential solar electricity adoption: What motivates, and what matters? A case study of early adopters. Energy Res. Soc. Sci. 2014, 2, 183-191. [CrossRef]

51. Klepacka, A.M.; Florkowski, W.J.; Meng, T. Clean, accessible, and cost-saving: Reasons for rural household investment in solar panels in Poland. Resour. Conserv. Recycl. 2018, 139, 338-350. [CrossRef]

52. Noll, D.; Colleen, D.; Rai, V. Solar community organizations and active peer effects in the adoption of residential PV. Energy Policy 2014, 67, 330-343. [CrossRef] 
53. Sheth, J.N.; Newman, B.I.; Gross, B.L. Why we buy what we buy: A theory of consumption values. J. Bus. Res. 1991, 22, 159-170. [CrossRef]

54. Rizkalla, N. Appraising the influence of theory of consumption values on environmentally-friendly product purchase intention in Indonesia. Manag. Mark. J. 2020, 18, 7-25.

55. Lin, J.; Guo, J.; Turel, O.; Liu, S. Purchasing organic food with social commerce: An integrated food-technology consumption values perspective. Int. J. Inf. Manag. 2020, 51, 102033. [CrossRef]

56. Pousa, C.; Núñez, J.F. Why Do Consumers Buy Fair Trade Products? An Evolutionary Perspective Using the Theory of Consumption Values. J. Manag. Sustain. 2014, 4, 1. [CrossRef]

57. Lin, P.C.; Huang, Y.H.; Wang, J. Applying the Theory of Consumption Values to Choose Behavior toward Green Products. In Proceedings of the 5th IEEE International Conference on Management, Innovation and Technology ICMIT 2010, Singapore, 2-5 June 2010; pp. 348-353.

58. Teng, C.-I. Look to the future: Enhancing online gamer loyalty from the perspective of the theory of consumption values. Decis. Support Syst. 2018, 114, 49-60. [CrossRef]

59. Varshneya, G.; Pandey, S.K.; Das, G. Impact of Social Influence and Green Consumption Values on Purchase Intention of Organic Clothing: A Study on Collectivist Developing Economy. Glob. Bus. Rev. 2017, 18, 478-492. [CrossRef]

60. Khan, S.N.; Mohsin, M. The power of emotional value: Exploring the effects of values on green product consumer choice behavior. J. Clean. Prod. 2017, 150, 65-74. [CrossRef]

61. Awuni, J.A.; Du, J. Sustainable Consumption in Chinese Cities: Green Purchasing Intentions of Young Adults Based on the Theory of Consumption Values. Sustain. Dev. 2015, 24, 124-135. [CrossRef]

62. Gonçalves, H.M.; Lourenço, T.F.; Silva, G.M. Green buying behavior and the theory of consumption values: A fuzzy-set approach. J. Bus. Res. 2016, 69, 1484-1491. [CrossRef]

63. Suki, N.M. Consumption values and consumer environmental concern regarding green products. Int. J. Sustain. Dev. World Ecol. 2015, 22, 269-278. [CrossRef]

64. Lee, C.K.C.; Levy, D.S.; Yap, C.S.F. How does the theory of consumption values contribute to place identity and sustainable consumption? Int. J. Consum. Stud. 2015, 39, 597-607. [CrossRef]

65. Haws, K.L.; Winterich, K.P.; Naylor, R.W. Seeing the world through GREEN-tinted glasses: Green consumption values and responses to environmentally friendly products. J. Consum. Psychol. 2014, 24, 336-354. [CrossRef]

66. European Commission. A Policy Framework for Climate and Energy in the Period from 2020 to 2030; European Commission: Brussels, Belgium, 2014.

67. Wierzbowski, M.; Filipiak, I.; Lyzwa, W. Polish energy policy 2050-An instrument to develop a diversified and sustainable electricity generation mix in coal-based energy system. Renew. Sustain. Energy Rev. 2017, 74, 51-70. [CrossRef]

68. European Parliament. Directive 2009/28/EC of the European Parliament and of the Council of 23April 2009 on the promotion of the use of energy from renewable sources and amending and subsequently repealing Directives 2001/77/EC and 2003/30/EC (Text with EEA relevance). Off. J. Eur. Union 2009, 5, 16-62.

69. Statistics Poland. Energy from Renewable Sources in 2019; Statistics Poland: Warsaw, Poland, 2020.

70. Breyer, C.; Bogdanov, D.; Aghahosseini, A.; Gulagi, A.; Child, M.; Oyewo, A.S.; Farfan, J.; Sadovskaia, K.; Vainikka, P. Solar photovoltaics demand for the global energy transition in the power sector. Prog. Photovolt. Res. Appl. 2018, 26, 505-523. [CrossRef]

71. Institute of Renewable Energy. The Photovoltaic Market in Poland (Rynek Fotowoltaiki w Polsce); Institute of Renewable Energy, 2017. Available online: https: / /ieo.pl/pl/projekty/raport-rynek-fotowoltaiki-w-polsce-2017 (accessed on 7 January 2021).

72. Nicosia, F.M. Consumer Decision Processes: Marketing and Advertising Implications; Prentice-Hall: Englewood Cliffs, NJ, USA, 1966.

73. Engel, J.F.; Kollat, D.T.; Blackwell, R.D. Consumer Behavior; Holt Rinehart and Winston: New York, NY, USA, 1968.

74. McCarthy, J.E.; Perreault, W.D.; Quester, P.G. Basic Marketing: A Managerial Approach; Irwin: Sydney, Australia, 1997.

75. Yeo, B.L.; Mohamed, R.H.N.; Muda, M. A Study of Malaysian Customers Purchase Motivation of Halal Cosmetics Retail Products: Examining Theory of Consumption Value and Customer Satisfaction. Procedia Econ. Financ. 2016, 37, 176-182. [CrossRef]

76. De Groot, J.I.M.; Steg, L. Value Orientations to Explain Beliefs Related to Environmental Significant Behavior. Environ. Behav. 2007, 40, 330-354. [CrossRef]

77. Urien, B.; Kilbourne, W. Generativity and self-enhancement values in eco-friendly behavioral intentions and environmentally responsible consumption behavior. Psychol. Mark. 2010, 28, 69-90. [CrossRef]

78. Biswas, A.; Roy, M. Green products: An exploratory study on the consumer behaviour in emerging economies of the East. $J$. Clean. Prod. 2015, 87, 463-468. [CrossRef]

79. Sweeney, J.C.; Soutar, G.N. Consumer perceived value: The development of a multiple item scale. J. Retail. 2001, 77, 203-220. [CrossRef]

80. Ottman, J. Sometimes, consumers will pay more to go green. Mark. News 1992, 26, 16.

81. Wang, H.; Ma, B.; Bai, R. How Does Green Product Knowledge Effectively Promote Green Purchase Intention? Sustainability 2019, 11, 1193. [CrossRef]

82. Connell, K.Y.H. Internal and external barriers to eco-conscious apparel acquisition. Int. J. Consum. Stud. 2010, 34, 279-286. [CrossRef]

83. Gleim, M.R.; Smith, J.S.; Andrews, D.; Cronin, J.J. Against the Green: A Multi-method Examination of the Barriers to Green Consumption. J. Retail. 2013, 89, 44-61. [CrossRef] 
84. Padel, S.; Foster, C. Exploring the gap between attitudes and behaviour. Br. Food J. 2005, 107, 606-625. [CrossRef]

85. Vermeir, I.; Verbeke, W. Sustainable food consumption among young adults in Belgium: Theory of planned behaviour and the role of confidence and values. Ecol. Econ. 2008, 64, 542-553. [CrossRef]

86. Nunes, P.A.; Schokkaert, E. Identifying the warm glow effect in contingent valuation. J. Environ. Econ. Manag. 2003, 45, 231-245. [CrossRef]

87. Yue, B.; Sheng, G.; She, S.; Xu, J. Impact of Consumer Environmental Responsibility on Green Consumption Behavior in China: The Role of Environmental Concern and Price Sensitivity. Sustainability 2020, 12, 2074. [CrossRef]

88. Ecker, F.; Hahnel, U.J.J.; Spada, H. Promoting Decentralized Sustainable Energy Systems in Different Supply Scenarios: The Role of Autarky Aspiration. Front. Energy Res. 2017, 5, 14. [CrossRef]

89. Salazar, H.A.; Oerlemans, L.; Van Stroe-Biezen, S. Social influence on sustainable consumption: Evidence from a behavioural experiment. Int. J. Consum. Stud. 2012, 37, 172-180. [CrossRef]

90. Lee, K. The Green Purchase Behavior of Hong Kong Young Consumers: The Role of Peer Influence, Local Environmental Involvement, and Concrete Environmental Knowledge. J. Int. Consum. Mark. 2010, 23, 21-44. [CrossRef]

91. Gadenne, D.; Sharma, B.; Kerr, D.; Smith, T. The influence of consumers' environmental beliefs and attitudes on energy saving behaviours. Energy Policy 2011, 39, 7684-7694. [CrossRef]

92. Hartmann, P.; Ibáñez, V.A.; Sainz, F.J.F. Green branding effects on attitude: Functional versus emotional positioning strategies. Mark. Intell. Plan. 2005, 23, 9-29. [CrossRef]

93. Choi, Y.; Cui, L.; Li, Y.; Tian, X. Focused and ambidextrous catch-up strategies of emerging economy multinationals. Int. Bus. Rev. 2020, 29, 101567. [CrossRef]

94. Cerjak, M.; Mesić, Z.; Kopić, M.; Kovačić, D.; Markovina, J. What Motivates Consumers to Buy Organic Food: Comparison of Croatia, Bosnia Herzegovina, and Slovenia. J. Food Prod. Mark. 2010, 16, 278-292. [CrossRef]

95. Lorenzoni, I.; Nicholson-Cole, S.; Whitmarsh, L. Barriers perceived to engaging with climate change among the UK public and their policy implications. Glob. Environ. Chang. 2007, 17, 445-459. [CrossRef]

96. Lin, P.-C.; Huang, Y.-H. The influence factors on choice behavior regarding green products based on the theory of consumption values. J. Clean. Prod. 2012, 22, 11-18. [CrossRef]

97. Muñoz, J.I.; De La Nieta, A.A.S.; Contreras, J.; Bernal-Agustín, J.L. Optimal investment portfolio in renewable energy: The Spanish case. Energy Policy 2009, 37, 5273-5284. [CrossRef]

98. Crago, C.L.; Chernyakhovskiy, I. Are policy incentives for solar power effective? Evidence from residential installations in the Northeast. J. Environ. Econ. Manag. 2017, 81, 132-151. [CrossRef]

99. Yoo, J.-J.; Divita, L.; Kim, H.-Y. Environmental awareness on bamboo product purchase intentions: Do consumption values impact green consumption? Int. J. Fash. Des. Technol. Educ. 2013, 6, 27-34. [CrossRef]

100. Rahnama, H.; Rajabpour, S. Identifying effective factors on consumers' choice behavior toward green products: The case of Tehran, the capital of Iran. Environ. Sci. Pollut. Res. 2017, 24, 911-925. [CrossRef]

101. Tsarenko, Y.; Ferraro, C.; Sands, S.; McLeod, C. Environmentally conscious consumption: The role of retailers and peers as external influences. J. Retail. Consum. Serv. 2013, 20, 302-310. [CrossRef]

102. Liobikienè, G.; Bernatonienè, J. Why determinants of green purchase cannot be treated equally? The case of green cosmetics: Literature review. J. Clean. Prod. 2017, 162, 109-120. [CrossRef]

103. Goworek, H.; Fisher, T.; Cooper, T.; Woodward, S.; Hiller, A. The sustainable clothing market: An evaluation of potential strategies for UK retailers. Int. J. Retail. Distrib. Manag. 2012, 40, 935-955. [CrossRef]

104. Kaiser, F.G.; Scheuthle, H. Two challenges to a moral extension of the theory of planned behavior: Moral norms and just world beliefs in conservationism. Pers. Individ. Differ. 2003, 35, 1033-1048. [CrossRef]

105. Chen, Y.; Chang, C. Enhance green purchase intentions: The roles of green perceived value, green perceived risk, and green trust. Manag. Decis. 2012, 50, 502-520. [CrossRef]

106. Eze, U.C.; Ndubisi, N.O. Green Buyer Behavior: Evidence from Asia Consumers. J. Asian Afr. Stud. 2013, 48, 413-426. [CrossRef]

107. Thompson, A.; Tong, X. Factors influencing college students' purchase intention towards Bamboo textile and apparel products. Int. J. Fash. Des. Technol. Educ. 2016, 9, 62-70. [CrossRef]

108. Groves, R.M.; Fowler, F.J.; Couper, M.P.; Lepkowski, J.M.; Singer, E.; Tourangeau, R. Survey Methodology; Wiley: New York, NY, USA, 2011.

109. Norstat. Norstat Panelbook. Available online: www.norstatgroup.com (accessed on 6 January 2021).

110. Baruch, Y. Response Rate in Academic Studies-A Comparative Analysis. Hum. Relat. 1999, 52, 421-438. [CrossRef]

111. Sakshaug, J.W.; Yan, T.; Tourangeau, R. Nonresponse Error, Measurement Error, and Mode of Data Collection: Tradeoffs in a Multi-mode Survey of Sensitive and Non-sensitive Items. Public Opin. Q. 2010, 74, 907-933. [CrossRef]

112. Werner, S.; Praxedes, M.; Kim, H.-G. The Reporting of Nonresponse Analyses in Survey Research. Organ. Res. Methods 2007, 10, 287-295. [CrossRef]

113. Lee, M.K.O.; Turban, E. A Trust Model for Consumer Internet Shopping. Int. J. Electron. Commer. 2001, 6, 75-91. [CrossRef]

114. Arvola, A.; Vassallo, M.; Dean, M.; Lampila, P.; Saba, A.; Lähteenmäki, L.; Shepherd, R. Predicting intentions to purchase organic food: The role of affective and moral attitudes in the Theory of Planned Behaviour. Appetite 2008, 50, 443-454. [CrossRef]

115. Dholakia, U.M. A motivational process model of product involvement and consumer risk perception. Eur. J. Mark. 2001, 35, 1340-1362. [CrossRef] 
116. Hirschman, E.C. Innovativeness, Novelty Seeking, and Consumer Creativity. J. Consum. Res. 1980, 7, 283-295. [CrossRef]

117. Tarrant, M.A.; Cordell, H.K. The Effect of Respondent Characteristics on General Environmental Attitude-Behavior Correspondence. Environ. Behav. 1997, 29, 618-637. [CrossRef]

118. Gerbing, D.W.; Anderson, J.C. An Updated Paradigm for Scale Development Incorporating Unidimensionality and Its Assessment. J. Mark. Res. 1988, 25, 186. [CrossRef]

119. Hair, J.; Black, W.; Babin, B.; Anderson, R. Multivariate Data Analysis; Prentice-Hall: Upper Saddle River, NJ, USA, 2010.

120. Thakkar, J.J. Introduction to structural equation modelling. In Studies in Systems, Decision and Control; Springer: Singapore, 2020; pp. 1-11. [CrossRef]

121. Schumacker, R.E. A Beginner's Guide to Structural Equation Modeling; Routledge: London, UK, $2012 ;$ ISBN 9780203851319.

122. Preedy, V.R.; Watson, R.R. (Eds.) Handbook of Disease Burdens and Quality of Life Measures; Springer: New York, NY, USA, 2010; ISBN 978-0-387-78664-3.

123. Fornell, C.; Larcker, D.F. Evaluating structural equation models with unobservable variables and measurement error. J. Mark. Res. 1981, 18, 39-50. [CrossRef]

124. Podsakoff, P.M.; MacKenzie, S.B.; Podsakoff, N.P. Sources of method bias in social science research and recommendations on how to control it. Annu. Rev. Psychol. 2012, 63, 539-569. [CrossRef] 